\title{
Exploration on the New Direction of Teaching Management in Colleges and Universities
}

\author{
Lixin Fan \\ School of Humanities, Jilin Agricultural University, Changchun 130118, China. \\ 897146503@qq.com
}

\begin{abstract}
In the era of the development of knowledge economy, there is higher requirements being put forward on the development of the quality of a talent. Every country is facing the fierce international competition and the challenge of new technological revolution. International environment brings a huge opportunity for the development of higher education in our country, but on the other hand it also makes that our country's higher education is facing enormous pressure and challenges. China is in a transition period of market economy and knowledge economy, the developing pace of popularization of higher education is comparatively rapid. In the background of internationalization, networking and information technology, people continue to go towards diversified developing direction. The development of inclusive education and lifelong education and the development of learning society requires us to continue to study and research to solve the problems existing in and will be faced in the development of higher education in China.
\end{abstract}

Keywords: Colleges and universities; Teaching management; Exploration; Countermeasures.

\section{Introduction}

\subsection{Research Background and Significance}

Colleges and universities is the base for cultivating advanced specialized talents, while teaching is the main process and means of education in the important mission of higher education to complete the cultivation of talents. Teaching is the fundamental work and the center of school, and in Colleges and universities, the management of teaching process is implemented by the teaching management departments. Therefore, colleges and universities teaching management mode is particularly important, which is directly related to the university personnel training quality and the prospects for universities' development. In the traditional university management process, China lacks understanding of and respect for the essence of people's value, with little consideration to individual needs, interests, hobbies and so on of teachers' and students' who are regarded as the main body of the management in Colleges and universities, and in the daily management it also lacks democracy management atmosphere. In the existing teaching management model, it still exists some objective factors that suppress or even hinder the all-round development of people, and along with the development and change of the society, the negative effect is becoming more and more obvious and the impact is bigger and bigger. As a result, to improve the teaching management mode is an inevitable requirement of deepening the teaching reform in Colleges and universities.

\subsection{Theoretical Research}

Teaching management, teaching management mode, and management pattern are taken as the key words in the CNKI to carry out the search, and its retrieval result is as shown in Table 1.

Table 1 Statistical table of taking teaching management, teaching management mode, and management mode as key words to retrieve

\begin{tabular}{|c|c|c|}
\hline $\begin{array}{c}\text { Search words } \\
\text { CNKI search results (articles) }\end{array}$ & Key words & Article name \\
\hline Teaching management & 59899 & 15345 \\
\hline Teaching management mode & 9418 & 1395 \\
\hline Management mode & 9 & 2 \\
\hline
\end{tabular}

Note: data statistics in the table is counted by the end of July 21, 2016. 
From the above results, we can see that in recent years, scholars in China have paid more attention to the research of teaching management in Colleges and universities, but there are few studies on the teaching management mode of universities.

\section{Theoretical Interpretation of Teaching Management Mode}

\subsection{Definition of the Concept of Teaching Management Mode in Colleges and Universities}

(1) Mode and Management Mode

Mode refers to the theoretical summary formed by the abstract analysis of the existence of a kind or a group of things or the form of movement by people. Management mode means, under the guidance of certain management thought, the integration of management objectives of organizations, management philosophy, management object, management content and management tools, management program, management means and management system in order to promote the effective functioning of the organization, and distinctive and stable state management formed in the long-term practice of management.

(2) Teaching Management Mode in Colleges and Universities

College teaching management mode is a kind of management system which is built around student management, discipline construction, teaching facilities, teacher management and so on in Colleges and universities. Teaching management is the basic activities of the management of Colleges and universities, and Colleges and universities management is the core. According to the certain education principle, teaching plan and teaching outline requirements, taking teaching sub-system as the research object, using the modern management theories and methods, by means of scientific management to organize and use human, material and financial resources to implement scientific management in the process of teaching, and eventually achieve the optimal allocation of educational resources to obtain the best effect in teaching.

\subsection{Comparison of Three Teaching Management Modes (Table 2)}

\section{Problems Existing in the Teaching Management Mode in Colleges and Universities in China}

\subsection{Unclear Boundaries between Academic Power and Administrative Power}

The management system of higher Colleges and universities in our country is operated by the maintenance of the academic power and administrative power binary structure. The main task of higher education reform in our country is around with how to rationalize the management relationship, lean management mechanism, and improve the efficiency of management. But the relationship between academic power status and role as well as relationship between academic power and administrative power are rarely discussed. Whereas, China's bureaucracy management mode of teaching has the following shortcomings. First of all, it has very complex hierarchical structure, the serious thought of "official standard", and the unclear boundaries of administrative power and academic power; secondly, administrative power generalization phenomenon is serious, "agency" color of university teaching management is too strong, and the phenomenon that intervene or replace the academic power with administrative power is relatively common.

\subsection{Lack of Autonomy of Teaching Activities Persons}

In the talent training mode of Colleges and universities, the premise of students' individual development is students' autonomous learning, which is the basic embodiment of the freedom of the higher education in students' learning. But in the teaching plan and setting of professional settings, Colleges and universities follows the principle of step-by-step and rigid design pattern is serious. The teaching management system with strong rigidity seriously hinders students' individual development and ignores the needs of diverse learning in the process of students' development, resulting in that the students lack interest and initiative in learning. 
Table 2 Comparison of three teaching management modes

\begin{tabular}{|c|c|c|}
\hline $\begin{array}{l}\text { Teaching } \\
\text { management } \\
\text { modes } \\
\text { Items }\end{array}$ & Advantages & Disadvantages \\
\hline $\begin{array}{c}\text { Continental } \\
\text { division system }\end{array}$ & $\begin{array}{l}\text { 1. College entrance, personnel, } \\
\text { curriculum and other teaching policies are } \\
\text { state-regulated, and authorize specific } \\
\text { academic authority to manage the teaching, } \\
\text { so that the academic management formation } \\
\text { of Universities is increasingly standardized } \\
\text { and structured. } \\
\text { 2. Teaching management formation } \\
\text { depends on the law and policy, standards, } \\
\text { hierarchy and specific authority positions. } \\
\text { 3. The focus of academic power is on the } \\
\text { grassroots level. Academic power decreases } \\
\text { in turn from the lecture to the lecture meeting } \\
\text { and to the academic committee in the } \\
\text { academic level. }\end{array}$ & $\begin{array}{l}\text { The obvious weakness of this teaching } \\
\text { management pattern is its lack of flexibility, } \\
\text { their dependence on the specific environment } \\
\text { and too stable task structure. The standardized } \\
\text { model it implements hinders the development of } \\
\text { academic and differentiation of management } \\
\text { mechanism. The centralized hierarchy is bound } \\
\text { to adjust organizational conflict rather than to } \\
\text { seek for organizational change and development } \\
\text { through the political behavior of interest groups. }\end{array}$ \\
\hline $\begin{array}{l}\text { British } \\
\text { community } \\
\text { style }\end{array}$ & $\begin{array}{l}\text { 1. The typical feature of British } \\
\text { universities teaching management is relying } \\
\text { on the professional judgment as a solution to } \\
\text { the conflict; manage the teaching work } \\
\text { according to the common value concept; the } \\
\text { teaching management of Colleges and } \\
\text { universities in the UK relies more on } \\
\text { potential professional norms and authority of } \\
\text { professional personnel. } \\
\text { 2. Its advantage is that it can mobilize the } \\
\text { collective wisdom and used to solve the } \\
\text { problems in teaching management. }\end{array}$ & $\begin{array}{l}\text { The disadvantage of the British higher } \\
\text { education management model is that the } \\
\text { academic tradition hinders the formation of the } \\
\text { bureaucratic control and organization } \\
\text { innovation. }\end{array}$ \\
\hline $\begin{array}{c}\text { China's } \\
\text { administrative } \\
\text { centralization }\end{array}$ & $\begin{array}{l}\text { 1. It has the characteristics of hierarchy } \\
\text { teaching management mode. } \\
2 \text {. The administrative power is in pyramid } \\
\text { form, the upper the level, the more } \\
\text { concentrated the administrative power. }\end{array}$ & $\begin{array}{l}\text { 1. The status of academic power is not paid } \\
\text { attention to, which is not conducive to promote } \\
\text { the enthusiasm of academic staffs. } \\
2 \text {. Basic level staffs including teachers and } \\
\text { administrators are not fully involved in the } \\
\text { development and implementation of teaching } \\
\text { management planning and decision-making } \\
\text { process, which is contrary to the essential } \\
\text { requirements of academic organizations. }\end{array}$ \\
\hline
\end{tabular}

\subsection{Lack of Effective Teacher Performance Evaluation Mechanism}

At present in teaching management mode of Chinese Colleges and university, there are some problems existing in the teaching performance evaluation of teachers. First of all, it pays too much attention to scientific research and despises teaching. Currently China's Colleges and universities generally regards teaching and scientific research as the important content of evaluating teachers' performance indexes. Teaching activities results are "soft" results to scientific research, and the effect is lag, which is often difficult to measure. Secondly, it lays too much emphasis on quantitative methods while despises the application of qualitative methods. Moreover, it lays too much emphasis on rewards and punishments but neglects the development of teachers. This is not conducive to the smooth progress of performance evaluation, but also hinders the future career development of teachers and the long-term development of the school. 


\section{Countermeasures of Improving the Teaching Management in Colleges and Universities}

\subsection{Constructing Democratic Participation Mechanism of Teachers and Students}

In Colleges and universities, the subject of academic power is mainly professors, associate professors and other teaching staff who are engaged in teaching and scientific research. The object of academic power mainly refers to all kinds of academic affairs, academic activities and academic relationships in universities. Because the main function of Colleges and universities is to cultivate talents and academic research, there is a strong academic in work content. The engagement of university teachers in teaching and research is mostly independent work, uneasy to be unified commanded or set a unified implementation of the standard, and it is necessary to comply with the objective laws of education itself. In the university teaching management mode, it is important to establish the core position of academic power in the teaching management. According to modern education theory, teachers and students are the main body of school teaching, so it is required to timely mobilize the enthusiasm and initiative of teachers and students to participate in school management.

\subsection{Establishing the Interests of Teachers and Students}

(1)Establish Teaching Management System with People-oriented, Flexible Management-based, and Rigid Management-supplemented

The teaching management system is the embodiment of teaching idea, teaching theory and the idea The transformation of teaching thought idea is the forerunner of teaching management reform and the power of teaching management system renewal. Management concept is a guide to school's development, and it is a directional and fundamental problem, which marks that the development of higher education enters into a new era. Management concept is the foundation and soul of university management work, and it is the intensive embodiment of school positioning and management thinking. It is the ideal and the value of personnel role positioning and management features in Colleges and universities. Management concept is not abstract, so it is impossible to talk about the concept of university management divorced from the reality of the university. The key of teaching management system reform is to give more options and free choice to teachers and students. Only by giving teachers and students with more space and opportunities can it in a large extent satisfy the needs of teachers and students' individual development.

(2)Improve People's Emotional Recognition through Active Training

Teacher in-service training is an effective way to change teachers' concept, improve teachers' quality and the ability of teaching and learning, so as to achieve the professional development of teachers. Overall, in the training of each link, it is necessary to take into account the various needs of teachers, reflect the humanistic care, and consider the actual situation of teachers in the teaching time arrangement as far as possible. University teaching management personnel should constantly improve their own quality, implement a regular training system: post job training, management theory training, and management technology training. Managers should fairly treat every one of the teachers, establish mutual trust atmosphere and common expectations to all members in the school, improve teachers' work, and encourage every one of the teachers become self-managers and self-leaders.

\subsection{Implement Incentive Evaluation Mechanism}

(1)Scientifically Establish Teacher Performance Evaluation Standard

University teachers are the important force of national knowledge innovation and the important part of the teaching management in universities. Playing the essential role of teachers is the key to promote the university management system, the innovation of mechanism and the construction of the system. Teachers' evaluation is the process of making value judgment for teachers' performance and effectiveness, and teaching competency and professional development ability in the teaching activities. The purpose is to improve teaching efficiency and promote teachers' professional development, which is the indispensable link in a university management system reform and innovation. Teacher evaluation is an important measure to improve the level of teachers in the reform and innovation of university management system, and it in the deep level influences the support 
function of higher education to economic and social development. First of all, combining with the actual development of university, make teachers' performance evaluation standards and rules. Secondly, internalize the university teachers' performance evaluation standard in teacher's activities. More importantly, strengthen the performance evaluation of teachers with the help of a variety of means.

(2)Accurately Grasp the Evaluation Criteria of Student Success

Evaluation criteria for College students' success refers to the success specification identified in the evaluation of talent of College students. Evaluation standard of College students' success is to examine college students' success evaluation according to certain educational goals and specific targets from the perspective of higher education, and the key is to serve the general goal and specify it. The general goal of higher education is determined on the basis of the strategic task of our country's education at present, and it is the starting point and the foothold of the evaluation of College students' success. Due to the evaluation of the objective is often an abstract summary, in practice it is difficult to directly take it as a basis for evaluation. Therefore, it is necessary to make the abstract objective specific, and then it is decomposed into specific indicators. Specific, measurable behavior and operational objectives can be used as a direct basis for evaluation. But the index can only reflect a content of the evaluation. Only by forming a set of interrelated index system can it possible to fully and scientifically proceed evaluation of College students.

\section{Conclusion}

As China's higher education transfers from elite education to mass education, the internationalization of higher education is facing the challenge. How to change the school teaching and management mode in order to improve the development of Colleges and universities is the focus of attention of the whole society. The advantages and disadvantages of College teaching management mode are compared and analyzed, and draw a conclusion that in the teaching management in Colleges and universities, it is necessary to proceed around the main body of "people", implement the people-oriented teaching management, and build a people-oriented College teaching management mode. Starting from the analysis of advantages and disadvantages of teaching management mode, aiming at the problems existing in the current mode of teaching management in Colleges and universities in China, this paper puts forward countermeasures of constructing democratic participation mechanism of teachers and students, establishing the interests of teachers and students, and implementing incentive evaluation mechanism.

\section{References}

[1] Danhong M A. Application of Delicacy Management in Teaching Management of Colleges and Universities [J]. Ibm Corporation, 2015.

[2] Zhan-Yan L. Study on Evaluation System of Teaching Management Execution in Colleges and Universities[C]// 2015 Conference on Informatization in Education, Management and Business (IEMB-15). Atlantis Press, 2015.

[3] Shi L, Zhang Y. Application of Computer Technology in Sports Teaching Management of Colleges and Universities[C]// Fourth International Conference on Instrumentation and Measurement, Computer, Communication and Control. IEEE, 2014:92-102.

[4] Sheng H. On the New Direction of Hierarchical English Teaching Reform in Engineering Colleges and Universities: A Discussion from "Guide to College English Teaching (Exposure Draft)"[J]. Science Education Article Collects, 2015. 